\title{
Cardiac troponin T quantitative assay failure as a result of antibody interference
}

\begin{tabular}{|c|c|}
\hline \multicolumn{2}{|c|}{$\begin{array}{l}\text { Authors: } \\
\text { Philip H. Fortgens } s^{1,2} \\
\text { Fierdoz Omar }\end{array}$} \\
\hline \multicolumn{2}{|c|}{$\begin{array}{l}\text { Affiliations: } \\
{ }^{1} \text { Department of Clinical } \\
\text { Laboratory Sciences, Division } \\
\text { of Chemical Pathology, } \\
\text { University of Cape Town, } \\
\text { South Africa }\end{array}$} \\
\hline \multicolumn{2}{|c|}{$\begin{array}{l}{ }^{2} \text { National Health Laboratory } \\
\text { Service, Groote Schuur } \\
\text { Hospital, South Africa }\end{array}$} \\
\hline \multicolumn{2}{|c|}{$\begin{array}{l}\text { Correspondence to: } \\
\text { Philip Fortgens }\end{array}$} \\
\hline \multicolumn{2}{|c|}{$\begin{array}{l}\text { Email: } \\
\text { philip.fortgens@nhls.ac.za }\end{array}$} \\
\hline \multicolumn{2}{|c|}{$\begin{array}{l}\text { Postal address: } \\
\text { Division of Chemical } \\
\text { Pathology, University of } \\
\text { Cape Town/National Health } \\
\text { Laboratory Service, Groote } \\
\text { Schuur Hospital, Anzio Road, } \\
\text { Observatory, Cape Town, } \\
7925\end{array}$} \\
\hline \multicolumn{2}{|c|}{$\begin{array}{l}\text { Received: } 09 \text { Dec. } 2011 \\
\text { Accepted: } 20 \text { Sep. } 2013 \\
\text { Published: } 03 \text { Dec. } 2013\end{array}$} \\
\hline \multicolumn{2}{|c|}{$\begin{array}{l}\text { How to cite this article: } \\
\text { Fortgens PH, Omar F. Cardiac } \\
\text { troponin T quantitative assay } \\
\text { failure as a result of antibody } \\
\text { interference. Afr J Lab Med. } \\
\text { 2013;2(1), Art. \#23, } 3 \text { pages. } \\
\text { http://dx.doi.org/10.4102/ } \\
\text { ajlm.v2i1.23 }\end{array}$} \\
\hline \multicolumn{2}{|c|}{$\begin{array}{l}\text { Copyright: } \\
\text { C 2013. The Authors. } \\
\text { Licensee: AOSIS } \\
\text { OpenJournals. This wo } \\
\text { is licensed under the } \\
\text { Creative Commons } \\
\text { Attribution License. }\end{array}$} \\
\hline \multicolumn{2}{|l|}{ Read online: } \\
\hline 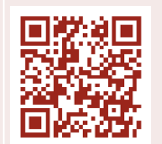 & $\begin{array}{l}\text { Scan this QR } \\
\text { code with your } \\
\text { smart phone or } \\
\text { mobile device } \\
\text { to read online. }\end{array}$ \\
\hline
\end{tabular}

Background: Immunoassays are prone to interference by various substances which may cause inaccurate results. This type of interference is difficult to detect analytically.

Objective: A case of CARDIAC Troponin T Quantitative reader (Roche Diagnostics) assay failure was detected and investigated in order to ascertain the likely cause.

Method: Patient whole blood was mixed with cardiac troponin T-positive blood, patient and control sera were denuded of immunoglobulin $G$ by protein A-affinity chromatography and patient sera were mixed with mouse serum. Samples were analysed on a CARDIAC Troponin T Quantitative reader.

Results: A mixture of patient whole blood and cardiac troponin T-positive blood resulted in assay failure; removal of immunoglobulin $\mathrm{G}$ from patient sera reversed the cardiac troponin $\mathrm{T}$ assay failure; the addition of mouse serum as a heterophile antibody blocking agent had no effect.

Conclusion: It is proposed that the interference resulting in assay failure may not be because of a heterophile antibody, but rather a result of a circulating autoantibody to cardiac troponin $\mathrm{T}$, which may compete with antibody assay reagents for binding sites.

\section{Introduction}

A consensus document released by the European Society of Cardiology, the American College of Cardiology, the American Heart Association and the World Heart Federation task force in 2012 has proposed cardiac troponin (cTn) as the preferred biomarker for myocardial necrosis because of its superlative myocardial tissue specificity and high clinical sensitivity. ${ }^{1}$ Furthermore, cTn has also been shown to have value for the prediction of adverse cardiovascular events in patients presenting with acute coronary syndrome. ${ }^{2}$ Cardiac troponin $\mathrm{T}$ (cTnT) appears to be an important marker of coronary heart disease, mortality and risk of heart failure in a healthy population without manifest cardiovascular disease. ${ }^{3}$

Measurement of cardiac troponins is achieved by immunoassay. Despite extensive experience with this methodology, however, immunoassays are occasionally subject to interfering substances that compromise their accuracy - indeed, it is estimated that antibody interference affects approximately one in 2000 immunoassay results. ${ }^{4}$ We report a novel case of assay failure using the CARDIAC Troponin T Quantitative reader (Roche Diagnostics).

\section{Research method and design Case}

A 61-year-old female, with a history of ischaemic heart disease and hypertension, presented to the emergency unit on two occasions 12 days apart with chest discomfort. Repeated attempts by the diagnostic laboratory to obtain cTnT measurements failed, as reflected by the absence of a positive control line on test strips (CARDIAC Troponin T Quantitative reader, Roche Diagnostics; Figure 1). As the creatinine kinase level was within normal limits (26-140 U/L) at both visits and the myoglobin was normal (7-64 ng/L) when measured at the second visit, the patient was discharged with follow-up.

\section{Interference experiments}

Antibody interference was suspected and the following investigation was thus performed. Prior ethics approval was not obtained as the investigation would lead to improvement in this patient's management. Firstly, a 1:1 mixture of the patient's sample and a recently-assayed anonymous sample positive for cTnT (both heparinised whole bloods), was assayed for cTnT. ${ }^{5}$ Secondly, patient and control plasma samples were depleted of immunoglobulin G (IgG) using 
protein A-affinity chromatography. ${ }^{6}$ These samples were analysed for cTnT prior to and after IgG depletion. The CARDIAC Troponin T Quantitative reader is a lateral flow immunoassay, utilising the sandwich principle on a test strip with two murine monoclonal anti-cTnT antibodies. ${ }^{7}$ Thirdly, in order to exclude the presence of interfering human antimouse antibodies (HAMA), mouse serum was added to the patient plasma (1:4) and the mixture was incubated for one hour at room temperature, following which the cTnT was measured. Lastly, to determine whether the automated cTnT assay on the Roche Elecsys E170 analyser was subject to the same interference, dilutions of a known cTnT-positive plasma sample mixed with the patient plasma were assayed for cTnT.

\section{Results}

The mixture of whole blood patient sample and a cTnTpositive specimen inhibited the formation of the control line on the cTnT reagent strip, supporting our suspicion of an interfering substance. Whilst only the control sample elicited a control line prior to IgG depletion $(\mathrm{cTnT}<0.03 \mathrm{ng} / \mathrm{ml})$, both the patient and control samples elicited control lines after $\mathrm{IgG}$ depletion $(\mathrm{cTnT}<0.03 \mathrm{ng} / \mathrm{ml}$ ), suggesting that $\mathrm{IgG}$ was the interfering substance. Test-strips contain HAMAblocking antibodies, ${ }^{7}$ but despite the presence of additional blocking agent (mouse serum), the control line did not develop, which suggested strongly that the interfering IgG was not an HAMA (Table 1). Dilutions of a known cTnTpositive plasma sample with the patient plasma showed a linear response when assayed for cTnT on the Roche Elecsys E170 analyser, suggesting that this platform is not subject to the same autoantibody interference.

\section{Discussion}

There is increasing use of cTn measurement in the diagnosis of myocardial injury and any inaccuracy with regard to measured values is more likely to have serious clinical impact than would be the case with immunoassays for many other analytes. Several immunochemical interferences have been well described, including heterophile antibodies, ${ }^{8}$ rheumatoid factor $^{9}$ and circulating troponin autoantibodies. ${ }^{10,11}$ Recent studies have shown that $15.9 \%$ of samples from cohorts of normal blood donors were positive for autoantibodies to troponin $\mathrm{T}$ or troponin I and $10.9 \%$ were positive for both. ${ }^{12}$ Autoantibody-antigen macrocomplexes have been well described for a number of biomarkers such as salivary amylase ${ }_{,}^{13}$ creatine kinase, ${ }^{14}$ aspartate aminotransferase ${ }^{15}$ and lactate dehyrogenase, ${ }^{16}$ but there is no evidence to suggest that these complexes contribute to a pathological process. In contrast, cTn autoantibodies have been shown to contribute to the progression toward heart failure in mice and a similar process may occur in humans. ${ }^{17}$ Furthermore, it has been proposed that the reduced clearance of immunoglobulincardiac troponin complexes from the circulation may result in increased levels of measured troponins. ${ }^{18}$ This phenomenon does not, therefore, represent assay interference, but rather an analytically-true result, albeit misleading.

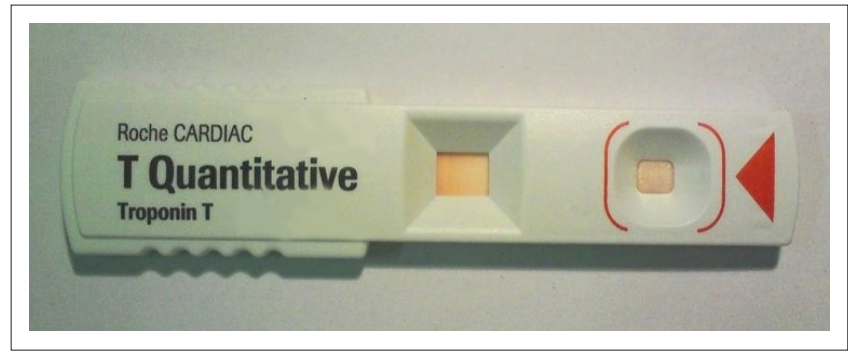

FIGURE 1: Absence of a control line on the Roche CARDIAC Troponin T Quantitative test strip.

TABLE 1: CARDIAC Troponin T Quantitative test strip performance.

\begin{tabular}{ll}
\hline Sample tested & Control line \\
\hline Patient whole blood & Absent \\
cTnT-positive whole blood & Present \\
Patient whole blood + cTnT-positive whole blood (1:1) & Absent \\
Protein A-affinity chromatography: control serum & Present \\
Protein A-affinity chromatography: patient serum & Present \\
Mouse blocking serum + patient plasma & Absent \\
\hline
\end{tabular}

cTnT, cardiac troponin $\mathrm{T}$.

This study shows that the removal of IgG from patient serum reverses the cTnT assay failure and that the addition of mouse serum as a heterophile antibody-blocking agent has no effect. This, together with the quantifiable result of the myoglobin assay (Roche Diagnostics), which uses the same test principle, species of monoclonal antibody and reader as the cTnT assay, suggests that the interference may not be because of a heterophile antibody, but rather because of an autoantibody to cTnT. Such an antibody may compete with the mouse anti-cTnT-gold complex for binding to immobilised cTnT on the test-strip, which normally serves as a test control. In the case of the myoglobin assay, the immobilised control antigen (myoglobin) is different, which may explain why it is unaffected. An autoantibody could also compete with reagent anti-cTnT antibodies for binding sites, thereby preventing the development of a test line (Figure 2).

There have been several reports of positive interference in the cTnT assay by heterophilic antibodies with the CARDIAC Troponin $\mathrm{T}$ Quantitative test $^{7}$ and the Elecsys $\mathrm{E} 170^{8}$ automated platform but, to the best of our knowledge, this is the first report of cTnT assay failure on the former platform. We conclude that the failure of this assay is a result of putative autoantibodies to cTnT. Assay failure also allowed for the immediate detection of potential interference, but the majority of cases of interference remain undetected at the analytical level. It is crucial, therefore, that any discrepancies between results and the clinical picture be addressed by clinicians with the laboratory, to avoid further potentiallyinvasive and expensive investigations.

\section{Conclusion}

A case of assay failure was detected in the CARDIAC Troponin T Quantitative reader. Immunoassays are subject to interference and it is important to investigate anomalous results to exclude such assay interference. After removing IgG from patient serum and re-assaying the cTnT, assay 


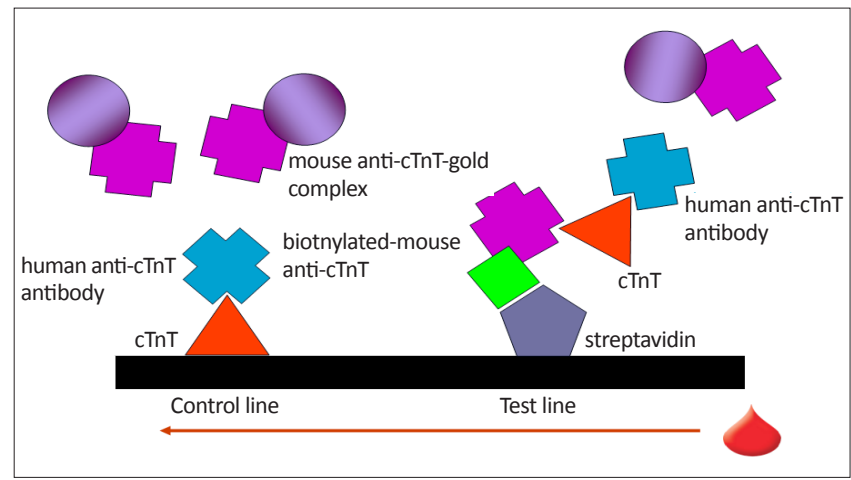

cTnT, cardiac troponin $\mathrm{T}$.

FIGURE 2: Possible effect of blocking human anti-cardiac troponin T antibodies on the Roche CARDIAC Troponin T Quantitative lateral flow immunoassay.

failure was found to reverse. This case highlights the fact that immunoassay interference remains a persistent problem and vigilance is encouraged in order to minimise its impact. Furthermore, in the case of troponins, interference may be caused by circulating autoantibodies to cTn.

\section{Acknowledgements}

We thank Noel Markgraaf for mouse serum, Roche Diagnostics for the Elecsys E170 troponin T assay kit and Dr Judy King for her critical appraisal of the manuscript.

This work was submitted as a presentation at the Federation of South African Pathology Societies $50^{\text {th }}$ Annual Congress, September 2010 and as a poster at the International Federation of Clinical Chemistry and Laboratory Medicine (IFCC) WorldLab and EuroMedLab Congress, Berlin, 2011.

\section{Competing interest}

The authors declare that they have no financial or personal relationship(s) that may have inappropriately influenced them in writing this article.

\section{Authors' contributions}

F.O. (University of Cape Town/NHLS) initiated the study, contributed to project design and critically revised the manuscript. P.H.F. (University of Cape Town/NHLS) contributed to study design, performed the experiments and wrote the manuscript.

\section{References}

1. Thygesen K, Alpert JS, Jaffe AS, et al. On behalf of the joint ESC/ACCF/AHA/WHF task force for the universal definition of myocardial infarction. Third universal definition of myocardial infarction. Eur Heart J. 2012;33:2551-2567. http:// dx.doi.org/10.1093/eurheartj/ehs184, PMid:22922414

2. Aldous SJ, Florkowski CM, Crozier IG, et al. High sensitivity troponin outperforms contemporary assays in predicting major adverse cardiac events up to two years in patients with chest pain. Ann Clin Biochem. 2011;48(Pt 3):249-255. http://dx.doi. org/10.1258/acb.2010.010220, PMid:21441393

3. Saunders JT, Nambi V, de Lemos JA, et al. Cardiac troponin T measured by a highly sensitive assay predicts coronary heart disease, heart failure, and mortality in the Atherosclerosis Risk in Communities study. Circulation. 2011;123(13):13671376. http://dx.doi.org/10.1161/CIRCULATIONAHA.110.005264, PMid:21422391, PMCid:PMC3072024

4. Levinson SS, Miller JJ. Towards a better understanding of heterophile (and the like) antibody interference with modern immunoassays. Clin Chim Acta. 2002;325(12):1-15. http://dx.doi.org/10.1016/S0009-8981(02)00275-9

5. Chan $\mathrm{AO}$, Chan JP, Choi KL, et al. A patient with an increased troponin level without evidence of ischaemic cardiac injury. Hong Kong Med J. 2004;10(4):277279. PMid:15299174

6. Selby C. Interference in immunoassay. Ann Clin Biochem. 1999;36(Pt 6):704-721. PMid:10586307

7. White $\mathrm{GH}$, Tideman PA. Heterophilic antibody interference with CARDIAC Quantitative Rapid Assay [Letter]. Clin Chem. 2002;48(1):201-202. PMid:11751561

8. Shayanfar N, Bestmann L, Schulthess G, et al. False-positive cardiac troponin T due to assay interference with heterophilic antibodies [Letter]. Swiss Med Wkly. 2008;138(31-32):470. PMid:18690561

9. Onuska KD, Hill SA. Effect of rheumatoid factor on cardiac troponin I measurement using two commercial measurement systems [Letter]. Clin Chem. 2000;46(2):307308. PMid:10657400

10. Bohner J, von Pape KW, Hannes W, et al. False-negative immunoassay results for cardiac troponin I probably due to circulating troponin I autoantibodies [Letter] Clin Chem. 1996;42(12):2046. PMid:8969651

11. Legendre-Bazydlo LA, Haverstick DM, Kennedy JL, et al. Persistent increase of cardiac troponin I in plasma without evidence of cardiac injury. Clin Chem. 2010;56(5):702705. http://dx.doi.org/10.1373/clinchem.2009.138164, PMid:20427735

12. Adamczyk M, Brashear RJ, Mattingly PG. Coprevalence of autoantibodies to cardiac troponin I and T in normal blood donors [Letter]. Clin Chem. 2010;56(4):676-677. http://dx.doi.org/10.1373/clinchem.2009.138099, PMid:20093555

13. Berk JE, Kizu H, Wilding $P$, et al. Macroamylasemia: a newly recognized cause for elevated serum amylase activity. N Engl J Med. 1967;277(18):941-946. http:// dx.doi.org/10.1056/NEJM196711022771801, PMid:4167531

14. Lee KN, Csako G, Bernhardt $P$, et al. Relevance of macro creatine kinase type 1 and type 2 isoenzymes to laboratory and clinical data. Clin Chem. 1994;40(7 Pt 1):1278-1283. PMid:8013099

15. Krishnamurthy $S$, Korenblat KM, Scott MG. Persistent increase in aspartate aminotransferase in an asymptomatic patient. Clin Chem. 2009:55(8):1573-1575. http://dx.doi.org/10.1373/clinchem.2008.120782, PMid:19638492

16. Fujita K, Takeya C, Saito T, et al. Macro lactate dehydrogenase: an LDHimmunoglobulin $\mathrm{M}$ complex that inhibits lactate dehydrogenase activity in a patient's serum. Clin Chim Acta 1984;140(2):183-195. http://dx doi. org/10.1016/0009-8981(84)90343-7

17. Wu AH. Cardiac troponin: friend of the cardiac physician, foe to the cardiac patient? Circulation. 2006;114(16):1673-1675. http://dx.doi.org/10.1161/ CIRCULATIONAHA.106.652123, PMid:17043176

18. Pettersson K, Eriksson S, Wittfooth S, et al. Autoantibodies to cardiac troponin associate with higher initial concentrations and longer release of troponin I in acute coronary syndrome patients. Clin Chem. 2009;55(5):938-945. http://dx.doi. org/10.1373/clinchem.2008.115469, PMid:19264856 